\title{
Potensi Bibit Sotong untuk Pengembangan Keragaman Budidaya Nelayan Kecil sebagai Strategi Konsevasi Lamun di Perairan Pesisir Lombok Timur
}

\section{The Potential of Cuttlefish Seedling for the Development of Diversity of Small Fishermen's Cultivation as a Seagrass Conservation Strategy in East Lombok Coastal Waters}

\author{
Abdul Syukur ${ }^{12 *}$, Agil Al-Idrus ${ }^{12}$, Lalu Muhammad Imam Husaini M. Nasir ${ }^{1}$, Pahmi $^{1}$ \\ ${ }^{1)}$ Program Studi Pendidikan IPA Pascasarjana Universitas Mataram \\ 2) Progran Studi Pendidikan Biologi PMIPA FKIP Universitas Mataram \\ Jl. Majapahit 62 Mataram 83125, Telp. (0370) 646506 INDONESIA \\ *corresponding author, email: syukurbiologi@unram.ac.id
}

Manuscript received: 15-11-2019. Accepted: 20-12-2019

\begin{abstract}
ABSTRAK
Diversifikasi budidaya laut memiliki nilai yang efektif untuk keberlanjutan matapencaharian nelayan kecil. Selain itu dapat berperan dalam menegah ancaman pemanfaatan yang tidak ramah lingkungan. Sotong adalah salah jenis komuditas biota laut yang memiliki nilai ekonomi tinggai dan memiliki potensi untuk dikembangkan sebagai kumoditas diversifikasi budidaya tingkat nelayan kecil. Tujuan penelitian ini adalah untuk mendeterminasi indikator potensi budidaya sotong sebagai strategi diversifikasi budidaya nelayan kecil dan konservasi lamun di lokasi studi. Metode penelitian yang digunakan adalah metode observasi langsung dan wawancara. Analisis data menggunakan analisis statistik diskriptif. Hasil penelitian menunjukkan rata-rata bibit sotong 1293.5 individu/bulan dan ratarata sotong hasil tangkapan nelayan yang didaratkan di TPI Tanjung Luar adalah 1229 individu/ bulan yang terdiri dari tiga spesies yaitu Sepia latimanus, Sepia pharaonis, dan Sepioteuthis lessoniana. Selain itu, budidaya laut telah berkembang menjadi pilihan matapencahrian nelayan kecil, meskipun masih bersifat komplementer. Selanjutnya, kelompok pembudidaya berperan aktif dalam mencegah ancaman lokal dari pemanfaatan yang tidak ramah lingkungan. Kesimpulan adalah diversifikasi budidaya dengan komuditas sotong adalah memiliki nilai strategis untuk mengatasi masalah keberlanjutan matapencaharian nelayan kecil dan konservasi lamun skala lokal di lokasi studi. Oleh karena itu, diversifikasi budidaya sotong dapat dipertimbangkan, khususnya pada skala nelayan kecil sebagai kebijakan pengembangan produk hasil laut untuk mencapai ketahan pangan, baik pada skala lokal, regional maupun nasional.
\end{abstract}

Kata kunci: lingkungan; diversifikasi; konservasi; potensi 


\begin{abstract}
Diversification of marine culture has an effective value for the sustainability of the livelihoods of small fishermen. In addition it can play a role in preventing the threat of utilization that is not environmentally friendly. Cuttlefish is one of the types of marine biota commodity that has high economic value and has the potential to be developed as a fishery diversification community. The purpose of this study was to determine the indicators of the potential of cuttlefish cultivation as a diversification strategy for small fishermen's cultivation and seagrass conservation in the study location. The research method used is the method of direct observation and interviews. Data analysis uses descriptive statistical analysis. The results showed that the average cuttlefish seedlings were 1293.5 individuals / month and the average cuttlefish caught by fishermen landed at TPI Tanjung Luar was 1229 individuals / month consisting of three species namely Sepia latimanus, Sepia pharaonis and Sepioteuthis lessoniana. In addition, marine cultivation has developed into the choice of livelihood for small fishermen, although it is still complementary. Furthermore, the group of farmers plays an active role in preventing local threats from uses that are not environmentally friendly. The conclusion is the diversification of cultivation with cuttlefish community is of strategic value to overcome the problem of the sustainability of small fishing livelihoods and local scale seagrass conservation in the study location. Therefore, diversification of cuttlefish culture can be considered, especially at the scale of small fishermen as a policy of developing seafood products to achieve food security, both at local, regional and national scale.
\end{abstract}

Keyword: environment; diversification; conservation; potential

\title{
PENDAHULUAN
}

Peningkatan populasi manusia telah menyebabkan permintaan yang lebih besar untuk produk perikanan. Oleh karena, Pengembangan teknologi akuakultur dibutuhakan sebagai strategi diversifikasi untuk peningkatan produksi perikanan, khususnya budaya laut. Salah satu komuditas yang memiliki nilai ekonomi tinggi untuk dibudidaya adalah sotong (cuttlefish). Cephalopoda memiliki potensi untuk menghasilkan revolusi dalam akuakultur dan sotong, kaya protein dan asam amino esensial serta memiliki kandungan karbohidrat dan lemak rendah, sehingga berkembang pesat dalam produksi akuakultur komersial (Iglesias et al. 2014). Selain itu, potensi sotong sebagai produk akuakultur menyebar di luar produksinya untuk konsumsi manusia, tinta untuk industri makanan manusia (sepia spaghetti) atau sebagai promotor fungsi kekebalan pada vertebrata (Liu et al. 2011), dan cuttlebone untuk industri obat dan farmakologis (Cadman et al. 2012, Kim et al. 2012). Cephalopoda memiliki tingkat pertumbuhan dan memiliki siklus kultur yang pendek, rasio produksi yang tinggi terhadap biomassa (Vidal et al. 2014).

Sotong adalah moluska yang termasuk kelas cephalopoda yang memiliki cirri-ciri cangkang internal yang terletak di dalam mantel berwarna putih, berbentuk oval dan tebal, serta terbuat dari kapur, tubuh relatif pendek menyerupai kantung, mantelnya berwarna merah jambu kehitaman dan diselubungi selaput tipis dan pada kedua sisinya terdapat sirip lateral yang memanjang dari ujung dorsal sampai ventral (Ozyurt et al. 2006). Pertumbuhan sotong tergolong cepat, dalam jangka waktu 45 sampai dengan 60 hari bisa mencapai bobot 50 gram, cepat dalam bereproduksi, jumlah telur banyak, serta daya tahan hidup anakan tinggi seiring dengan pemberian pakan yang sesuai sehingga dalam usaha membudidayakannya cukup mudah dan secara komersil mungkin akan memiliki dampak yang tinggi dalam produksi perikanan dalam waktu dekat (Sykes et al. 2014). Hal ini dapat menjadi sebuah pertimbangan untuk mengembangkan komoditas budidaya laut seperti budidaya sotong. 
Budidaya laut di lokasi studi telah menjadi sumber matapencaharian masyarakat dan jenis budidaya yang telah berkembang adalah budidaya lobster (Syukur et al. 2019). Namun demikian, budidaya lobster mengalami permasalahan dari regulasi Kementrian Kelautan dan Perikanan, berkaitan dengan ukuran hasil budidaya yang boleh diperdakangkan. Hal ini telah berdampak pada bertambahnya waktu pemeliharaan dan bertambahnya biaya pemeliharaan. Oleh sebab itu, alternatif pengembangan komuditas budidaya adalah solusi untuk mengatasi ketergantungan pembudidaya pada budidaya lobster. Salah satu komuditas yang memiliki potensi untuk dibudidaya adalah sotong (cuttlefish). Hal ini bertujuan untuk menjaga keberlanjutan matapencaharian pembudidaya dan mencegah mereka kembali sebagai pemburu biota laut yang bernilai ekonomi tinggi (tripang) pada eklosistem terumbu karang dan padang lamun. Sementara itu, keberadaan pembudidaya cukup efektif dalam mencegah eksploitasi sumberdaya laut dan ekosistemnya dengan cara tidak ramah lingkungan (Syukur et al. 2016). Hal lain yang sangat penting dari keberlanjutan budidaya adalah perannya untuk ketahanan pangan yang bersumber dari ikan (Unsworth et al. 2014).

Pengembangan budidaya ramah lingkungan yang berkelanjutan berkaitan dengan beberapa variabel yaitu: (1) kapasitas produksi, (2) pertumbuhan, (3) variabilitas, (4) pengaturan geografis dan sosial-ekonomi (5) sistem adat (tata nilai) masyarakat pesisir sebagai sistem produksi pangan melalui budidaya dan pengetahuan tentang regulasi dalam budidaya (Lee et al. 2014; Alappaththi \& Berkes, 2014). Selanjutnya produksi perikanan budidaya yang ramah lingkungan akan tergantung pada kombinasi yang tepat dari sistem manajemen kesehatan, penggunaan sumber daya dan spesies herbivora pada rantai makanan, penggunaan input yang tepat dan manajemen produksi (Lebel et al. 2010). selanjutnya, budidaya di wilayah pesisir memiliki relevansi yang signifikan untuk pengentasan kemiskinan dan sebagai instrumen untuk konservasi lamun (Syukur et al. 2019). Selain itu, pengembangan budidaya di lokasi studi dapat menjadi solusi dalam mengatasi berkurangnya hasil tangkapan nelayan dari jenis ikan target seperti cumi-cumi dan lemuru yang sudah melampaui potensi lestari (Santoso et al. 2015).

Pilihan pengembangan keragaman jenis budidaya sebagai sumber matapencaharian berkelanjutan adalah kompenen penting dalam program pengelolaan atau konservasi skala lokal. Salah satu program konservasi adalah mencegah degradasi lingkungan seperti pencegahan dsegradasi lamun dan ekosistemnya akibat penggunaan alat tangkap yang tidak ramah lingkungan seperti pukat dan sejenisnya (Grech et al. 2012). Hal ini bertujuan untuk menjaga fungsi ekologi lamun yang merupakan faktor esensial pada sistem trofik ikan dan ekonomi nelayan kecil (Nadiarti et al. 2012; de la Torre-Castro et al. 2014). Potensi budidaya laut di lokasi studi cukup mendukung pengembangan keragaman jenis budidaya, terutama dari potensi bibit (Syukur et al. 2015). Sotong adalah jenis komuditas budidaya yang belum banyak mendapat perhatian dari pembudiudaya di lokasi studi. Disisi lain belum ada data ilmiah sebagai dasar untuk pengembangan budidaya sotong. Oleh karena itu, tujuan penelitian ini adalah mendeterminasi indikator potensi budidaya sotong sebagai strategi diversifikasi budidaya nelayan kecil dan konservasi lamun di lokasi studi. Hasil penelitian ini dapat menjadi dasar pengembangan budidaya laut sebagai solusi dalam mengatasi keberlanjutan mata 
pencaharian nelayan dan konservasi lingkungan laut, khususnya di wilayah studi dan umumnya di wilayah perairan pesisir Propinsi Nusa Tenggara Barat.

\section{BAHAN DAN METODE}

Penelitian dilaksanakan dari bulan Maret sampai dengan bulan Agustus 2019 di wilayah perairan pesisir Selatan Pulau (Gambar 1). Data primer dari penelitian ini adalah bersumber dari hasil observasi langusng yaitu penanangkan bibit sotong dan survei hasil tangkapan nelayan. Pengambilan data bibit sotong dilakukan sore hari saat air laut sedang surut selama periode penelitian. Lokasi pengambilan data adalah areal lamun di Gili Kere, Poton Bakau, Lungkak dan Tanjung Luar. Alat yang digunakan adalah perlangkapan alat tangkap nelayan (Syukur et al. 2016). Sotong yang tertangkap diletakkan pada wadah penampungan untuk dihitung jumlahnya dan diukur panjangnya. Selain itu, dilakukan pengambilan data melalui survei tentang potensi sotong hasil tangkapan nelayan dan wawancara. Dalam hal ini, teknik sampling yang digunakan adalah pourposip sampling.

Kriteria nelayan sebagai responden adalah (1) meraka melakukan penagkapan ikan di sekitar areal padang lamun, (2) telah menjadi nelayan minimal 30 tahun dan (3) mengetahui sejarah budidaya di lokasi studi. Dalam hal ini, responden diberikan pertanyaan berkaitan dengan potensi bibit sotong pada perairan laut di sekitar lokasi studi, potensi sotong untuk dibudidayakan dan nilai positif budidaya untuk perlindungan sumberdaya laut, terutama dalam mencegah ancaman pemanfaatan yang tidak ramah lingkunga oleh masyarakat lokal.

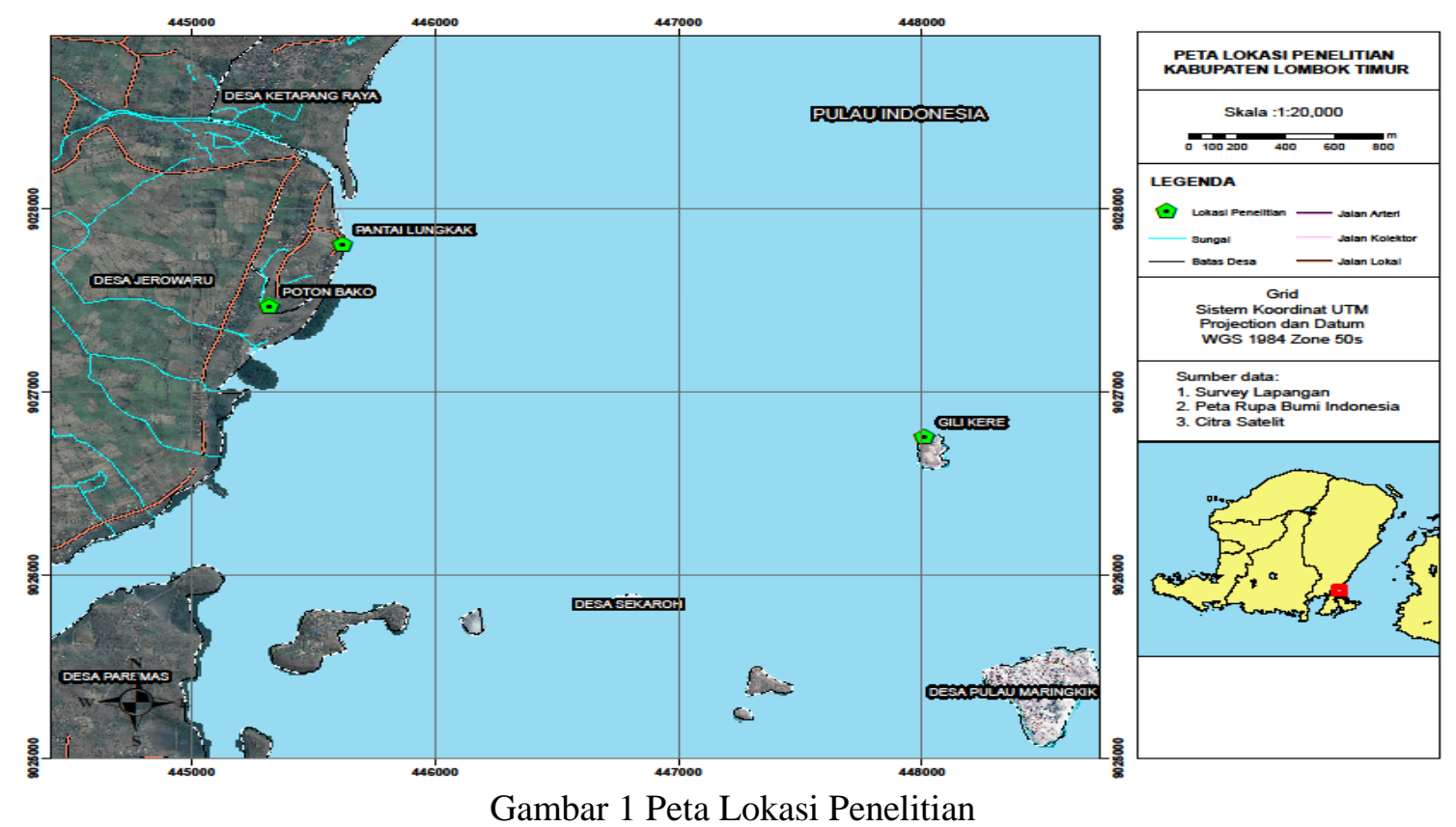

Pengumpulan data selanjutnya adalah data potensi sotong yang berasal dari hasil tangkapan nelayan. Pengambilan data dilakukan melalui melalui survei langusng hasil tangkapan nelayan yang di daratkan pada Tempat Pelelangan Ikan (TPI) Tanjung Luar Lombok Timur. Pemgambilan data dilakukan dari jam 6.00-10.00 Wita selama periode penelitian. Informasi yang dikumpulkan adalah jenis sotong, ukuran sotong dan harga (Rp). Data 
penelitian ditabulasi dan kelompokkan sesuai dengan karakternya. Selanjutnya, dilakukan analisis secara diskriptif dengan menggunakan analisis statistik diskriptif untuk mendapatkan nilai dengan bantuan Data yang diperolah dari hasil observasi dan wawancara ditabulasi sesuai dengan karakternya. Data dianalisis dengan menggunakan analisis statistik deskriptif untuk mendapatkan nilai tengah, rata-rata dan standar diviasi. Selanjutnya, dilakukan diskripsi untuk menjelaskan hubungan fungsional antar variable dalam penelitian ini.

\section{HASIL DAN PEMBAHASAN}

\section{Potensi Bibit Sotong pada di Lokasi Studi.}

Perairan laut di sekitar lokasi studi adalah areal tangkapan nelayan tradisional. Namun demikian, dalam perkembangannya pemanfaatan areal laut tidak hanya sebagai areal tangkapan tetapi dimanfaatkan untuk budidaya laut. Potensi budidaya didukung oleh potensi lingkungan laut dan potensi lobster dan bibit ikan ekonomis penting seperti ikan rabbit fishes, mullets, snappers, grants sweetlips dan goatfishes dan sebagai komplementer matapencaharian nelayan kecil (Bahrawi et al. 2014: Syukur et al. 2016). Potensi komuditas lain yang memiliki nilai ekonomi tinggi untuk dibudidayakan adalah sotong. Hasil observasi potensi bibit sotong selama periode penelitian adalah 7761 individu (Tabel 1). Hasil pengukuran sotong dikelompokkan menjadi tiga katogori yaitu $\leq 5 \mathrm{~cm}$ dengan jumlah $(62.16 \%), 6-7 \mathrm{~cm}(21.65 \%)$ dan $\geq 8 \mathrm{~cm} 16.17 \%$.

Tabel 1 Komposisi sotong berdasarkan ukuran $(\mathrm{cm})$ yang diperoleh pada lokasi studi.

\begin{tabular}{llllll}
\hline \multirow{2}{*}{ No } & Lokasi & \multicolumn{3}{c}{ Ukuran } & \multicolumn{2}{c}{ Jumlah Total } \\
\hline 1 & Tanjung Luar & 1138 & 414 & 308 & 1863 \\
2 & Gili Kere & 1725 & 341 & 408 & 2484 \\
3 & Lungkak & 1320 & 328 & 287 & 1940 \\
4 & Poton Bako & 642 & 598 & 252 & 1474 \\
\multirow{2}{*}{ Jumlah } & & 4825 & 1681 & 1255 & 7761 \\
\hline
\end{tabular}

Komposisi jumlah individu sotong (Tabel 1) dapat memberikan informasi tentang potensi bibit sotong di lokasi studi. Disamping itu, dapat menjadi acuan dalam minilai potensi sotong baik untuk penangkapan dan budidaya. Selanjutnya, komposi jumlah sotong yang diperoleh berdasarkan lokasi pengambilan contoh (Gambar 2). Lokasi dengan hasil tangkapan paling tinggi adalah di Gili sebesar (32\%) dan yang paling rendah adalah adalah Poton Bakau (19\%). Potensi bibit dan lokasi keberadaan bibit sotong adalah dua indikator yang dapat berkontribusi untuk pengembangan budidaya sotong di lokasi studi. Berkaitan dengan keberlanjutan budidaya pendekatan yang dibutuhkan adalah pendekatan ekologis, tetapi harus didukung dengan pemahaman ilmiah tentang hubungan antara lingkungan, dinamika trofik dan 
dinamika populasi dari komuditas budidaya (Rodhouse et al. 2014). Selain itu, penelitian di masa depan diperlukan, terutama yang fokus pada masalah yang berkaitan dengan produksi dan semua fase siklus hidup alamiah komuditas budidaya (Vidal et al. 2014).

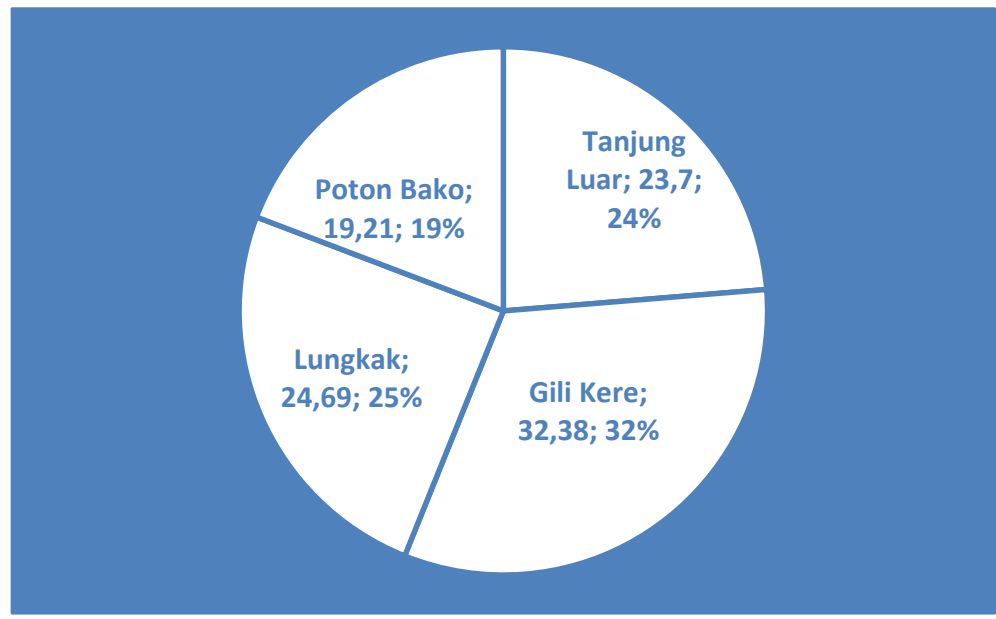

Gambar 2. \% Komposisi bibit sotong pada empat lokasi Padang Lamun di lokasi studi

\section{Potensi Budidaya Sotong Perpsektif Nelayan di Lokasi Studi}

Nelayan skala kecil adalah kelompok masyarakat terbesar dari semua komponen masyarakat yang tinggal di wilayah desa pantai. Berkaitan dengan nelayan kecil, khususnya di lokasi studi dihadapkan dengan situasi sulit, dimana hasil tangkapan cendrung tidak sesuai dengan biaya. Selain itu, dampak ekploitasi terutama sumberdaya dari ekosistem ekosistem mangrove, Padang Lamun dan terumbu karang adalah faktor yang telah berpengaruh terhadap ketersediaan sumberdaya ikan (Syukur et al. 2017). Oleh karena itu, pengembangan budidaya adalah solusi yang bersifat komplementer matapencaharian mereka selain sebagai nelayan. Hasil wawancara dengan pembudidaya, khususnya sotong dan mereka menyatakan cukup mudah dibudidaya tetapi membutuhkan kolam budidaya yang berbeda dengan komuditas budidaya yang lain.

Sotong di lokasi studi dikenal dengan nama "cumik lamun atau kenaus" dan penamaan ini erat hubungannya dengan lokasi untuk menangkap sotong. Hasil identifikasi yang telah dilakukan oleh nelayan sebagai responden lokasi atau areal tangkapan sotong di lokasi studi (Gambar 2). Hasil yang diperoleh adalah $60 \%$ responden menyatakan bahwa areal lamun adalah areal tangkapan sotong atau bibit sotong, $35 \%$ adalah areal sekitar terumbu karang dan $15 \%$ adalah areal lain. Hal ini dapat menjelaskan pertama nelayan memiliki pengetahuan sebagai sumber informasi tentang keberadaan sotong dan bibit sotong pada lingkungan perairan, (2) sotong dan bibit sotong tersebar merata pada pada semua tipe ekosistem di lingkungan laut dan (3) areal lamun adalah areal yang paling ideal untuk mencari sotong dan bibit sotong. Areal lamun sebagai lokasi ditemukannya sotong dan bibitnya adalah cukup relevan dengan fungsi ekologinya. Lamun di lingkungan memiliki fungsi sebagai tempat mencari makan (feeding grounds) dan tempat pemeliharaan (nursery grounds) dan salah satu fungsi vital lamun adalah berperan pada siklus hidup ikan termasuk sotong terutama pada saat 
masih massa juvenil (Hossain \& Saintilan, 2007). Aspek lainnya adalah nelayan melakukan penagkapan ikan dan sotong pada areal sekitar lamun adalah untuk keamanan alat tangkap.

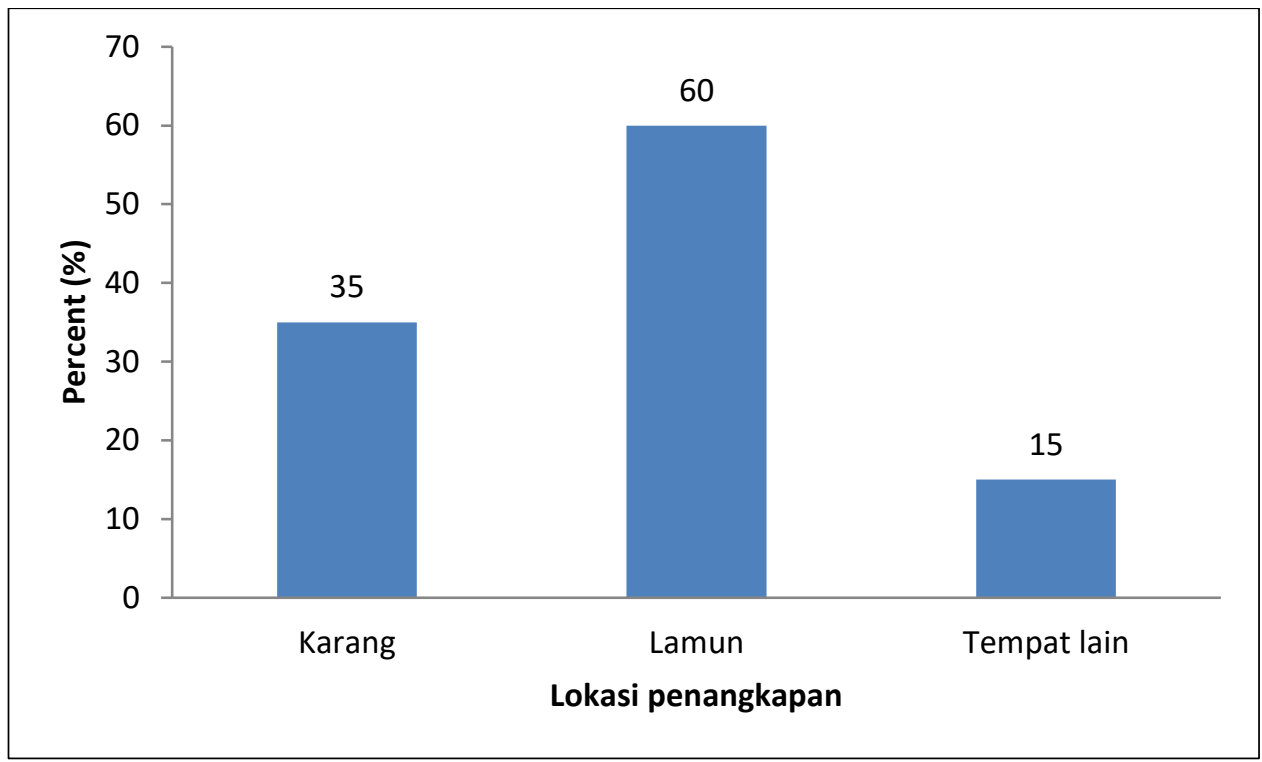

Gambar 3. Lokasi penangkapan bibit sotong di lokasi studi

Lokasi penangkapan bibit sotong seperti yang telah diuraikan di atas adalah gambaran objektif keberadaan alamiah sotong pada lingkungan laut. Selanjutnya, responden menjelaskan tentang kelimpahan bibit sotong dalam satu tahun (Gambar 3). Dalam hal ini, $45 \%$ menyatakan periode Januari- April adalah waktu paling baik untk mencari bibit sotong. Hal ini menggambarkan waktu memijah dari atau musim memijah dari sotong yang paling tinggi adalah pada saat mulai masuk musim hujan yaitu pada bula Desember. Selanjutnya, mereka mmenjelaskan bahwa musim hujan di lokasi studi rata-rata tiap tahun mulai bulan Desember.

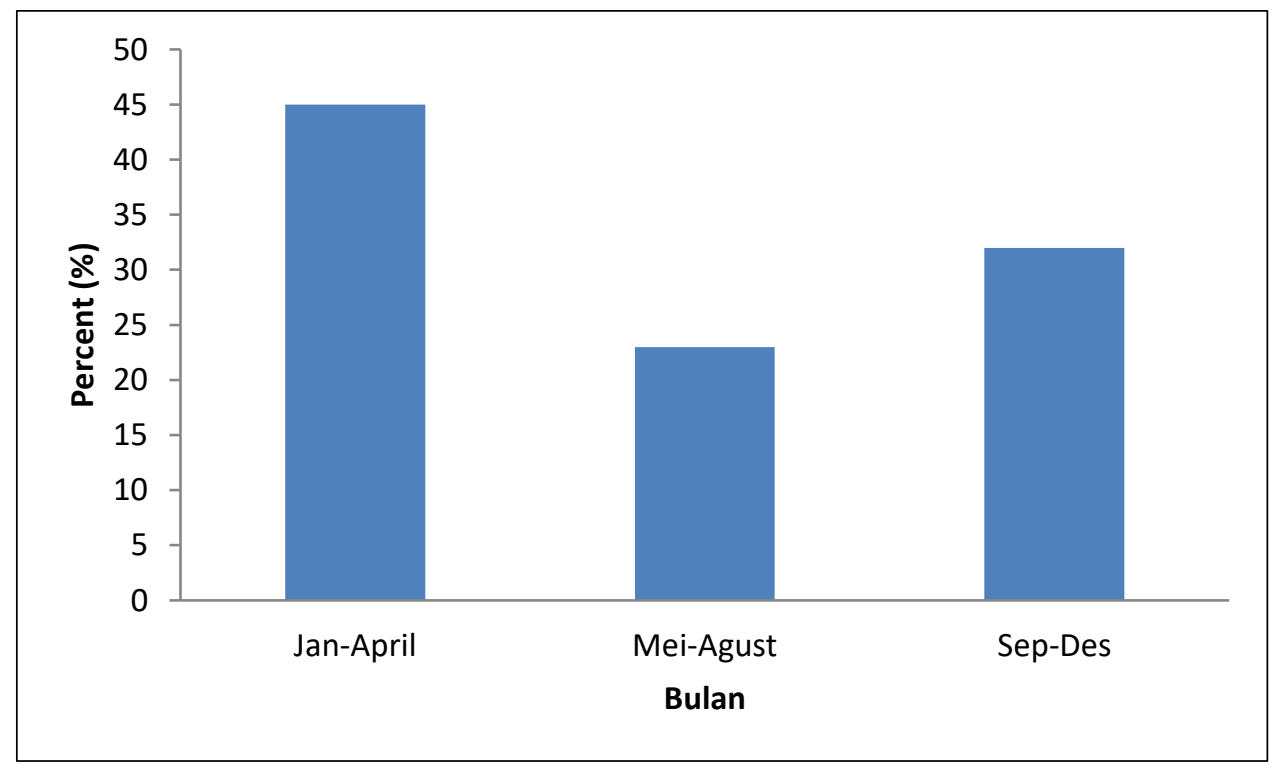

Gambar 4. Periodisasi kelimpahan bibit sotong dari perspktif nelayan di lokasi studi. 


\section{Potensi Sotong pada Tempat Pelelangan Ikan (TPI) Tanjung Luar Lombok Timur}

Sotong (cuttlefish) di wilayah studi adalah komuditas hasil perikanan yang memiliki nilai ekonomi tinggi. Hasil wawancara mendalam dengan nelayan sebagai responden menyatakan sotong tidak menjadi target tangkapan secara khusus. Namun demikian, sotong hasil tngkapan adalah bagain dari target keragaman jenis ikan yang memiliki nilai ekonomi tinggi. Hasil survei selama periode penelitian diperoleh tiga jenis sotong yang didaratkan di TPI Tanjung Luar (Table 2). Hal ini sama dengan jumlah spesies sotong yang didaratkan di TPI Muncar Banyuwangi Jawa Timur tiga spesies (Setyohadi et al. 2016). Namun demikian, Sepia esculenta, tidak ditemukan di lokasi studi.

Tabel 2. Jenis sotong dan harga jual/ekor

\begin{tabular}{lll}
\hline No & Nama Lokal & Nama Latin \\
\hline 1 & Kenaus & Sepia latimanus \\
2 & Cumi Parut & Sepia pharonis \\
3 & Cumi Lamun & Sepioteuthis lessoniana \\
\hline
\end{tabular}

Total 7374 individu sotong hasil tangkapan nelayan yang didaratkan di TPI Tanjung Luar dan rata-rata 1229 individu/bulan. Komposisi jumlah sotong selama periode penelitian (Gambar 5). Jumlah sotong paling tinggi adalah pada bulan Maret dan yang paling kecil pada bulan Agustus. Nilai ekonomi sotong untuk tiap spesies tidak sama dan dari hasil wawancara dengan pedagangdan konsumen yang paling dominan menentukan harga sotong adalah ukurannya. Hasil survei pada jenis sotong dari spesies Sepia latimanus dengan panjang mantel $21 \mathrm{~cm}$ rata-rata harganya berkisar antara Rp.50.000-Rp.70.000,/individu. Selanjutnya, sedangkan Sepia pharaonis dengan panjang mantel $30 \mathrm{~cm}$ rata-rata memiliki harga antara Rp.75.000- Rp. 85.000/individu, dan Sepioteuthis lessoniana dengan panjang mantel $27 \mathrm{~cm}$ rata-rata memiliki harga antara Rp.80,000-Rp.90.000/individu.

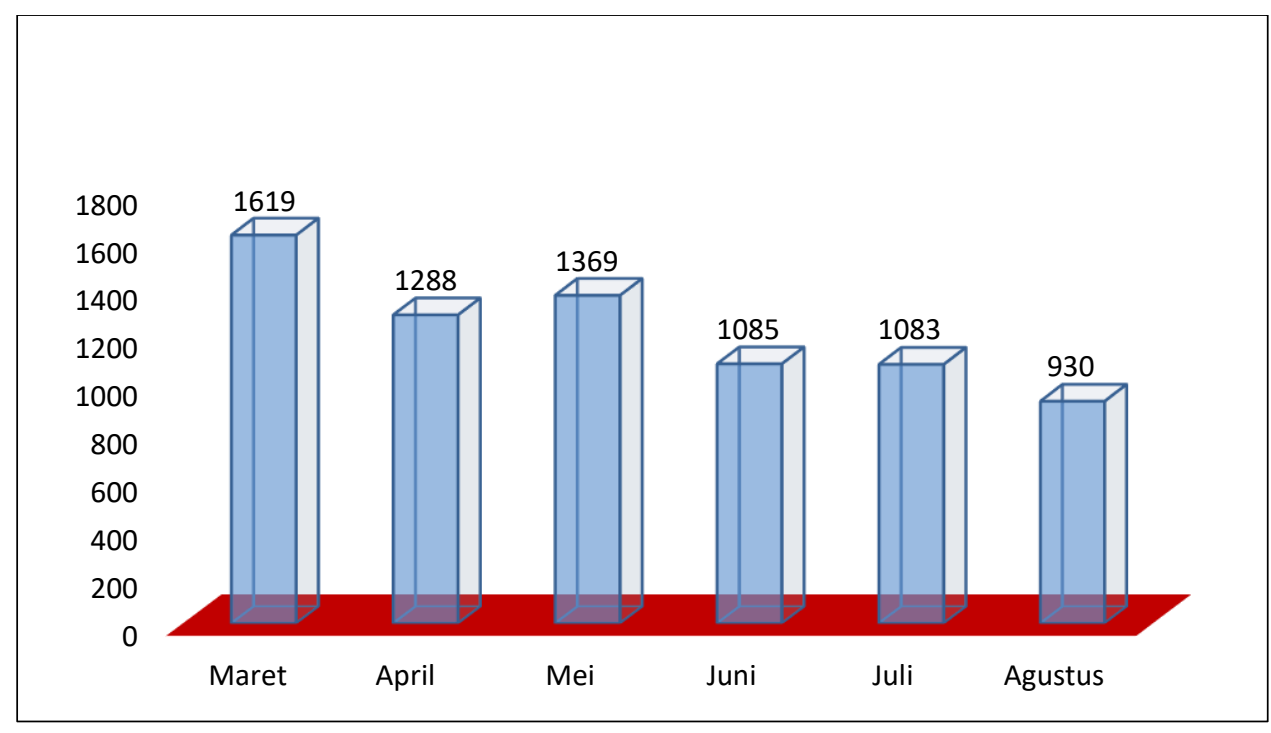

Gambar 5. Komposisi jumlah individu sotong hasil survei di TPI Tanjung Luar Lombok Timur 
Kragaman ukuran individu sotong hasil survei di TPI Tanjung Luar selama periode penelitian (Gambar 6). Sotong dengan ukuran mantel lebih kecil dari $15 \mathrm{~cm}$ rata-rata tiap bulan jumlahnya paling besar. Selanjutnya, sotong dengan ukuran mantel lebih besar dari $19 \mathrm{~cm}$ ratarata jumlahnya tiap bulan paling rendah. Hal ini menggambarkan keragaman ukuran sotong hasil tangkapan nelayan. Selain itu, dapat menggambarkan potensi sotong pada lingkungan perairan laut di lokasi. Namun demikian, karena sotong dengan ukuran lebih kecil dari $15 \mathrm{~cm}$ jumlah paling besar yang di daratkan di TPI Tanjung Luar dapat berdampak negatif terhadap keberlanjutan populasi sotong. Hal ini, disebabkan karena sotong yang akan mencapai ukuran matang gonad jumlahnya semakin sedikit. Selain itu, ukuran sotong yang lebih kecil memiliki haraga yang lebih rendah dan berpengaruh terhadap penghasilan nelayan.

Hasil wawancara mendalam dengan pedagang dan nelayan yang berkaitan dengan keberadaan sotong secara alami, mulai tahun 2010 sudah sangat kurang dibandingkan dengan antara tahun 1980 -1990an. Hal ini disebabkan oleh pengguaan alat tangkap yang tidak ramah lingkungan seperti bom, potassium. Berkaitan dengan hal ini, dibutuhkan usaha untuk menjaga stok sotong secara alami di lokasi studi. Salah satunya adalah melalui diversifikasi budidaya. Selain itu, hasil wawancara dengan nelayan keberadaan budidaya yang dimulai pada tahun 2010, khususnya di Tanjung Luar, Lungkak telah memberikan kontribusi untak mencegah penggunaan alat tangkap yang tidak ramah lingkungan.

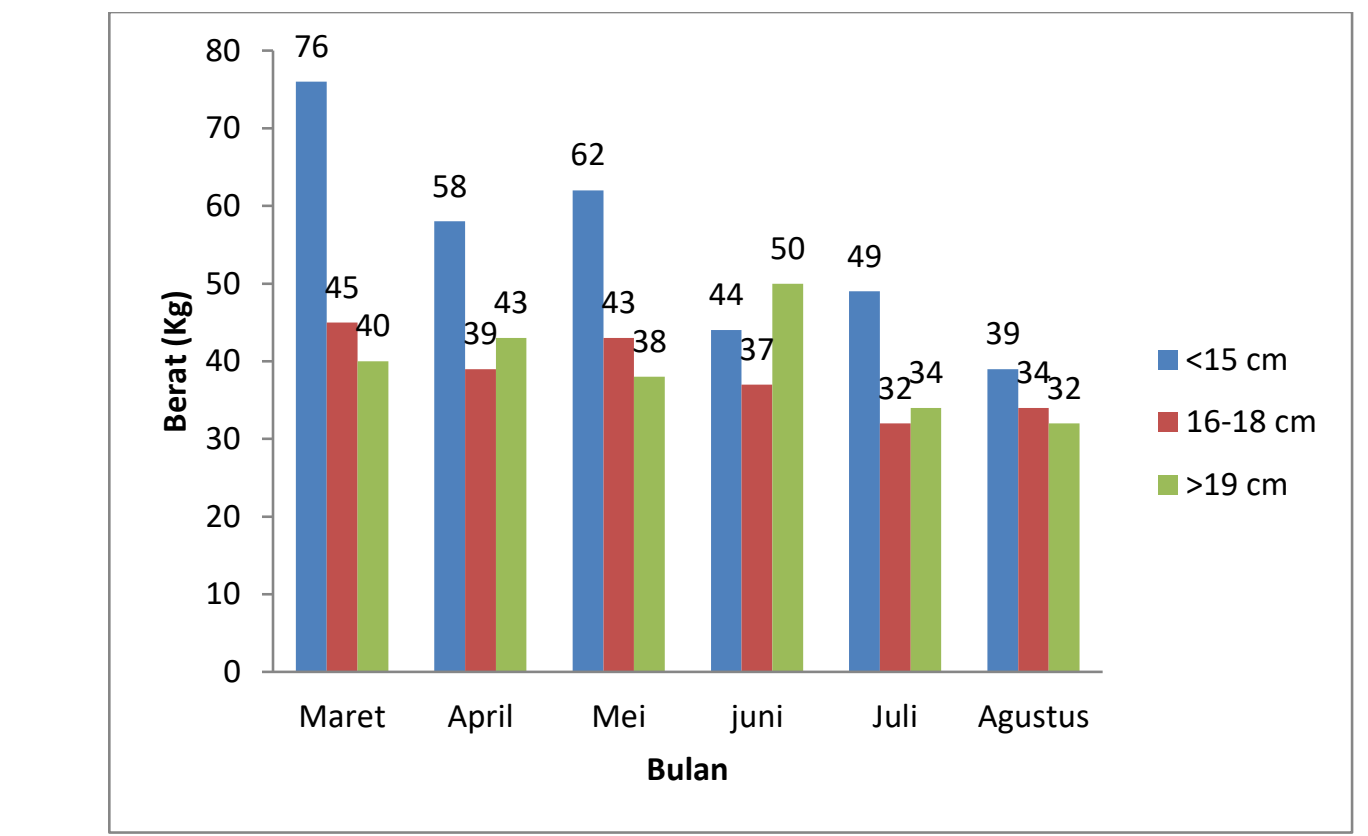

Gambar 6. Jumlah Sotong berdasarkan ukuran $(\mathrm{cm})$ dan berat $(\mathrm{kg})$ yang didaratkan pada TPI Tanjung Luar.

\section{KESIMPULAN}

Sotong adalah salah satu komuditas budidaya laut yang memiliki nilai ekonomi tinggi. Namun demikian, keberadaannya secara alami menunjukan telah terjadi penurunan produksi. Meskipun demikian, beberapa indiator menunjukkan memiliki potensi untuk diversivikasi budidaya. Indikatonya adalah potensi bibit, lingkungan perairan yang mendukung untuk 
pengembangan budidaya dan nilai ekonomi sotong yang cukup tinggi pada ukuran mantel yang telah mencapi lebih besar dari $30 \mathrm{~cm}$. Selain itu, budidaya sotong dapat meningkatkan peran secra aktif, khususnya nelayan pembudidaya dalam mencegah keberlanjutan penggunaan alat tangkap yang tidak ramah lingkunga

\section{Ucapan Terimakasih}

Tim peneliti menyampaikan ucapat terima kasih kepada Ritekdikti yang telah memberikan dana stimulus untuk pelaksanaan penelitian melalui program Penelitian Tesis Mahasiswa Tahun Anggaran 2019.

\section{DAFTAR PUSTAKA}

Bahrawi, S., Komarudin, A.K.U., dan Arfiyanto, A. 2014. Aplikasi penangkapan benih Lobster dengan menggunakan lampu. Direktorat Jenderal Perikanan Budidaya Departemen Perikanan dan Kelautan Republik Indonesia. Proseding Indonesia Aquaqulture 2014, Aquaculture for Bussines and Food Security, 344 hal.

Cadman, J., Zhou, S., Chen, Y., \& Li, Q. (2012). Cuttlebone: characterisation, application and development of biomimetic materials. Journal of Bionic Engineering, 9(3), 367-376.

Correia, M., Palma, J., \& Andrade, J. P. (2008). Effects of live prey availability on growth and survival in the early stages of cuttlefish Sepia officinalis (Linnaeus, 1758) life cycle. Aquaculture research, 39(1): 33-40.

de la Torre-Castro, M., Carlo, Gdi., dan, Jiddawi, N.S,. 2014. Seagrass importance for a smallscale fishery in the tropics: The need for seascape management. Mar Pollut Bull; 83:398-407.

Duysak, Ö. Özcan, G., Çek, Ş., \& Türeli, C. (2014). Reproductive biology of the common cuttlefish (Sepia officinalis Linnaeus, 1758) in Iskenderun Bay (Northeastern Mediterranean Sea). Indian journal of Geo-Marine Sciences, 43 (9): 56-65.

Galappaththi, E.K., dan Berkes, F. 2014. Institutions for managing common-pool resources: the case of community-based shrimp aquaculture in northwestern Sri Lanka. Maritime Studies, 3:1-16.

Grech, A., Chartrand-Miller, K., Erftemeijer, P., Fonseca, M., Kenzie, L. Mc., dan Rasheed M, 2012. A comparison of threats, vulnerabilities and management approaches in global seagrass bioregions. Environ Res Lett, 7:1-6.

Hossain, K., dan N. Saintilan. 2007. Lingkages between seagrass, mangrove and saltmarsh as fish habitat in the Botany Bay estuary, New South Wales. Wetlands Ecol Manage.15: 277-286.

Iglesias, J., Fuentes, L., Villanueva, R., 2014. Cephalopod Culture. Springer, Netherlands. 494 p. ISBN 978-94-017-8647-8

Kim, B. S., Kim, J. S., Sung, H. M., You, H. K., \& Lee, J. 2012. Cellular attachment and osteoblast differentiation of mesenchymal stem cells on natural cuttlefish bone. Journal of Biomedical Materials Research Part A, 100(7), 1673-1679. 
Lebel, L., Mungkung, R., Gheewala, S.H., dan LebelInnovation, P. 2010. Innovation cycles, niches and sustainability in the shrimp aquaculture industry in Thailand. Environmental Science and Policy, 13(4): 291-302.

Lee, S.Y., Primavera, J.H., Dahdouh-Guebas, F., Kee, K.Mc. Bosire, J.O., dan Cannicci, S. 2014.Ecological role and services of tropical mangrove ecosystems: a reassessment. Glob. Ecol.Biogeogr. 23:726-743.

Liu, H., Luo, P., Chen, S., \& Shang, J. 2011. Effects of squid ink on growth performance, antioxidant functions and immunity in growing broiler chickens. Asian-Australasian Journal of Animal Sciences, 24(12), 1752-1756.

Nadiarti, N.E, Djuwita, I., Budiharsono, S., Purbayanto, A., dan Asmus, H. 2012. Challenging for Seagrass Management In Indonesia. Journal of Coastal Develpopment, 15 (3): 234242Ozyurt G., Duysak O., Akamca E., Tureli C. 2006. Seasonal Changes of Fatty Acids of Cuttlefish Sepia Officinalis L. (Molusca: Cephalopoda) in the north eastern mediteranean sea. Food Cemistry 95 (3): 382-385.

Santoso, D., Baskoro, M.S, Simbolon, D., Novita, Y., dan Mustaruddin. 2015. The Status and Utilization Rate of Squid (Loligo edulis) in Alas Strait at West Nusa Tenggara Province. IJSBAR, 20 (2): 296-303.

Setyohadi, D., Sunardi, S., Mukhlis, N., \& Cahya, C. N. 2016. Cuttlefish (Sepia Spp) Identification and Biological Analysis of A Dominant Cuttlefish Species Landed in Muncar, Banyuwangi Regency, East Java. Research Journal of Life Science, 3(2): 109118.

Sykes, A.V., Domingues, P., Andrade, J.P., 2014. Sepia officinalis. In: Iglesias J, Fuentes L, Villanueva R (eds) Cephalopoda Culture. Spinger Netherland, hal 175-204.

Syukur, A, Mahrus, dan Syachruddin. 2015. Environment friendly fish farming and seagrass conservation as an instrument of economics development of small-scale fishermen in coastal waters of Tanjung Luar East Lombok. Paper presented in the International Seminar on Tropical Natural Resources, University of Mataram.

Syukur A., Mahrus, dan Syachruddin. 2016. The potential assessment environment friendly aquaculture of small-scale fishermen as a conservation strategy seagrass beds in coastal areas of Tanjung Luar East Lombok, Indonesia. International Journal of Fisheries and Aquatic Studies, 4 (2): 22-27.

Syukur, A., Mahrus, Syachruddin, AR. 2019. Relevansi Budidaya Ramah Lingkungan Terhadap Perlindungan Lamun Skala Lokal Di Pesisir Lombok Timur. JPPIPA: 5 (1): $1-12$.

Unsworth, R.K.F., Hinder, S.L, Bodger OG, dan Cullen-Unsworth, L.C. 2014. Food supply depends on seagrass meadows in the coral triangle. Environ Res Lett, 9:1-9.

Vidal, E. A., Villanueva, R., Andrade, J. P., Gleadall, I. G., Iglesias, J., Koueta, N., \& Albertin, C. B. (2014). Cephalopod culture: current status of main biological models and research priorities. In Advances in marine biology (Vol. 67, pp. 1-98). Academic Press. 